\title{
PENGARUH KOMUNIKASI PEMASARAN TERPADU DAN EKUITAS MEREK TERHADAP LOYALITAS KONSUMEN PADA CV. LARIS MOTOR CABANG AIR HAJI
}

\author{
Helmi Indra Pranata, Riri Mayliza \\ Sekolah Tinggi Ilmu Ekonomi KBP \\ indrarauang@gmail.com \\ ririmayliza@akbpstie.ac.id
}

\begin{abstract}
This study aims to determine the effect of Integrated Marketing Communication and Brand Equity on Consumer Loyalty on CV. Motorcycle Selling Air Haji Branch. The variables in this study are Integrated Marketing Communication (X1), Brand Equity (X2) and Consumer Loyalty (Y). 78 respondents were used, the sampling technique used was purposive sampling method. Data collection used questionnaires, while data analysis techniques were carried out using multiple linear regression analysis. The results showed that the integrated marketing communication variables had a positive and significant effect $(0.047$ $<0.05)$ on consumer loyalty decisions. Brand equity variables have a positive and significant effect on consumer loyalty $(0.003<0.05)$. It is expected that the next researcher will be able to use research as a reference which will provide a comparison in conducting further research and beneficial for companies.
\end{abstract}

Keywords: Integrated Marketing Communication, Brand Equity, Consumer Loyalty

\section{PENDAHULUAN}

Didalam era globalisasi sekarang ini dimana persaingan yang begitu ketat manusia dituntut untuk dapat menerapkan efisien dan efektivitas dalam aktifitasnya, begitu pula mobilitas dari lokasi satu ke lokasi lainnya.hal ini tentu akan berpengaruh terhaap alat transportasi yang ada, sepeda motor menjadi salah satu favorit masyarakat Indonesia karna dianggap lebih efektif dan efisien selain itu juga dianggaplebih mudah mendapatkan sepeda motor dibandingkan alat trasportasi lain seperti misalnya mobil dimana mayoritas masyarakat Indonesia adalah masyarakat dengan ekonomi kelas menengah bawah sehingga masyarakat Indonesia lebih banyak menggunakan sepeda motor dari pada menggunakan alat transportasi lain.

Dari masa ke masa pemakai sepeda motor.diIndonesia mengalami peningkatan hal ini tidak terlepas dari banyaknya perusahaan yang beroperasi dibidang penjualan sepeda motor.perusahan - perusahaan tersebut akan saling 
memberikan pelayanan dan saling bersaing untuk menapatkan hati para konsumen baik dengan komunikasi pemasaran secara langsung maupun tidak langsung

Kompetensi selalu terjadi didalam bisnis, tanpa adanya kompetensi tidak akanada pengembangan ide dan gagasan menuju perubahan yang lebih baik. Ketetatnya persaingan antar produk meningkatkan tendensi konsumen untuk beralih ke produk lain lebih lagi terhadap produk yang memiliki ketidak sesuaian antara nilai yang diberikan dengan ekspektasi konsumen (Chan, n.d.)

Perusahaan tidak bisa menghindari kompetisi jika tidak ingin terjadipenurunan market sharedisebabkan pasifnya memasarkan produk .situasi ini menunjukan betapa pentingnya memunculkan loyalitas dalam benak konsumen.

Loyalitas akan memunculkan perilaku pembelian produk secara berulang, sehingga cendrung lebih mendatangkan profit ketimbang berupaya menjaring konsumen baru setiap harinya, karena upaya tersebut menggunakan biaya yang tidak rendah (Darmawangsa, 2015).

Upaya ini pada dasarnya dimaksudkan untuk menjaga loyalitas konsumen agar konsumen tidak pindah ke perusahaan lainnya.dengan adanya strategistrategi atau inovasi baru diharapkan agar konsumen tiak pindah ke prusahaan lain dan tingkat penjualan sepeda motor prusahaan tetap stabil dan terjaga dengan baik.

Permasalahan yang sering muncul dalam aktifitas pejualan atau pemasaran produk sepeda motor di CV.Laris Motor Cabang Air Haji yaitu penguatan daya saing dari segi penjualan atau pemasaran maupun pelayanan yang selalu harus diperbaharui didalam mengahadapi kompetitor yang semakin mengeluarkan inovasi-inovasi dan ide-ide yang baru, yaitu seperti system pemasaran maupun pelayanan terhadap konsumen.

Begitu juga halnya dengan permasalahan loyalitas atau kesetiaan konsumen terhadap perusahaan yang mana masalahyang sering muncul adalah kurang nya strategi pemasaran yang secara efektif dan tepat sasaran yang dilakukan oleh perusahaan, dimna strategi pemasaran yang dilakukan perusahaan harus memiliki suatu inovasi baru yang lain dari pesaing-pesaing dalam hal ini diperlukan untuk menanamkan di benak masyarakat atas produk atau jasa yang perusahaan miliki. Dan juga perusahan perlu mencermati bahwa untuk meraih loyalitas konsumen tidak dengan diam menunggu konsumen membeli produknya saja.

Komunikasi pemasaran terpadu adalah strategi komperhensif pengomunikasian produk dengan menggabungkan elemen komunikasi yang bervariasi seperti periklanan, respon langsung, promosi penjualan, dan hubungan masyarakat untuk memberikan pengaruh komunikasi yang maksimum (Chan, n.d.)

Strategi pemasaran ini mampu menghemat biaya promosi dengan mengganti media promosi yang membutuhkan duplikasi contohnya brosur, pamphlet, menjadi strategi penyampaian produk secara inovatif dan kredibel sepertipengadaan pameran produk, penyisipan publisitas dimedia massa dan pembuatan website melayani transaksi jual beli (INTANI, 2016)

Semangkin ketatnya prersaingan menuntut CV.Laris Motor Cabang Air Haji untuk terus mengembangkan inovasi-inovasi strategi pemasaran yang baik, baik 
secara promosi dan penawaran yang kompetitif dengan persaingan sebagai upaya menguasai pasar dan pangsa pasar sepeda motor, strategi pemasaran tersebut juga dapat dilakukan dengan strategi yang berorientasi merek untuk menguatkan ekuitas mereknya melalui konsep pemasaran terpadu (integrated marketing communication)

(Maulidiah, n.d.) integrated market communicationadalah konsep dari perancangan komunikasi pemasaran yang mendatangkan nilai tambah dari rencana komprehensif.

\section{KAJIAN LITERATUR}

\section{Komunikasi Pemasaran Terpadu}

Indikator Komunikasi Pemasaran Terpadu

Tiga langkah dalam membagun komunikasi yang efektif menurut (Amstrong, 2009) :

a. Komunikasi pemasaran Melalui Iklan (Advertising)

b. Komunikasi pemasaran melalui promosi (Personal Selling)

\section{Ekuitas Merek}

c. Komunikasi pemasaran melalui sales promotion yaitu:

Menurut (Chan, n.d.), Indikator atau elemen ekuitas merek diantaranya
a. Kesadaran Merek
b. Asosiasi Merek
c. Persepsi kualitas
d. Loyalitas Merek
e. Aset Lain Yang Berkaitan Dengan Merek.

\section{Loyalitas Konsumen}

Menurut (Fathoni, n.d.)indicator dari loyalitas pelanggan adalah:

a. Repeat purchase (kesetian terhadap pembelian produk)

b. Retention (ketahanan terhadap pengaruh yang negative mengenai perusahaan)

c. Referrals (mereferensikan secara total esistensi perusahaan).

\section{METODE PENELITIAN}

\section{Populasi dan Sampel}

Populasi merupakan wilayah generalisasi yang terdiri atas subjek atau objek yang memiliki kuantitas dan karakteristik tersendiri yang ditetapkan oleh peneliti untuk dipelajari dan kemudian ditarik kesimpulannya (Sugiyono, 2015). Dapat disimpulkan bahwa populasi adalah keseluruhan subjek ataupun objek yang memiliki karakteristik berbeda dan bisa diteliti atau diamati. Populasi dalam penelitian ini adalah para pengguna atau pembeli produk sepeda motor merek Honda pada CV.Laris Motor Cabang Air Haji Pada rentang waktu dari bulan Maret- Agustus yang berjumlah 364 Orang.

Sampel merupakan bagian dari jumlah yang dimiliki populasi, untuk itu sampel yang diambil harus betul-betul mewakili (Sugiyono, 2015).Dapat disimpulkan bahwa sampel harus bisa mewakili keseluruhan subjek ataupun objek dalam penelitian.Dalam penelitian ini teknik pengambilan sampel yang digunakan 
adalah sampling jenuh dimana sampling jenuh adalah teknik pengambilan sampel bila semua anggota populasi digunakan menjadi sampel (Sugiyono, 2015). Sampel yang digunakan sebanyak 78 Orang pada pelanggan atau konsumen yang memakai produk sepeda moter merek Honda pada CV.Laris Motor Cabang Air Haji.

proporsi sebagai berikut:

$$
\mathrm{n}=\frac{\mathrm{N}}{1+\mathrm{N}(\mathrm{e})^{2}}
$$

Keterangan :

$$
\begin{aligned}
& \mathrm{n}=\text { Jumlah Sampel } \\
& \mathrm{N}=\text { Jumlah Total Populasi } \\
& \mathrm{e}=\text { Batas Toleransi Error }
\end{aligned}
$$

Pembahasan :

Diketahui : $\mathrm{N}=364$ orang

Ditanya $: \mathrm{n}=$ ?

$$
\mathrm{e}=10 \%(0,1)
$$

Jawab :

$$
\begin{aligned}
& \mathrm{n}=\mathrm{N} /\left(1+\mathrm{N} .(\mathrm{e})^{2}\right) \\
& \mathrm{n}=364 /\left(1+364 .(10 \%)^{2}\right) \\
& \mathrm{n}=364 /\left(1+364 .(0.1)^{2}\right) \\
& \mathrm{n}=364 /(1+364 .(0.01)) \\
& \mathrm{n}=364 /(1+3.64) \\
& \mathrm{n}=364 / 4.64 \\
& \mathrm{n}=78,44 \text { dibulatkan menjadi } 78 \text { orang }
\end{aligned}
$$

\section{Devenisi dan Operasional Variabel}

Dalam penelitian ini terdapat dua jenis variabel yaitu variabel bebas dan terikat. Adapun yang berperan sebagai variabel bebas adalah Komunikasi Pemasaran Terpadu, Ekuitas Merek dan loyalitas konsumen sebagai variabel terikat.

\section{Teknik Pengumpulan Data}

Pengukuran data dalam penelitian ini adalah angket atau kuisioner daftar pernyataan yang disusun berdasarkan kisi-kisi dalam bentuk skala likert (skala lima tingkat). Skala likert ( likert scale ) didesain untuk menalaah seberapa kuat subjek setuja atau tidak setuju dengan pertanyaan 5 titik dengan susunan sebagai berikut (Sekaran $2006: 29$ ), ( , angattidaksetuju $\quad=1$, Jawabantidaksetuju= 2, sedikit setuju $=3$, setuju $=4$, sangat setuju $=5$ ).

\section{Teknik Analisis Data}

Teknik analisis data yang digunakan adalah analisis deskriptif, uji validitas dan reabilitas, uji asumsi klasik dan analisis regresi linear

\section{Hasil dan Pembahasan}

Jumlah kuesioner yang diedarkan kepada responden sebanyak 78 eksamplar, seluruh kuesioner kembali seutuhnya karena penyebaran kuesioner dengan cara memberikan secara langsung dan ditunggu hingga selesai. 
Mayoritas responden adalah laki-laki yaitu sebanyak 64 orang $(82.1 \%)$ dan sisanya adalah perempuan yaitu sebanyak 14 Orang (19,9\%).

Profil responden kedua dibedakan atas usia. Berdasarkan kategori responden yang palinh banyak adalah usia 29 tahun - 34 tahun yaitu sebanyak 40 orang $(51,3 \%)$, kemudian usia 35 tahun -39 tahun sebanyak24 orang $(30,8 \%)$, kemudian usia antara 23 tahun- 28 tahun yaitu sebanyak 7 0rang (9\%).

Profil responden ketiga berdasarkan atas pekerjaan berdasarkan kategori yang paling banyak adalah yaitu (25,6\%), kemudian pegawai swasta sebanyak 18 orang $(23,1 \%)$, kemudian kariyawan sebanyak9 orang(11,5\%), dan lainnya sebanyak7 orang $(9 \%)$.

\section{Uji Validitas dan Reliabilitas}

Uji vadilitas adalah suatu tahap pengujian yang dilakukan terhadap isi (konten) dari suatu instrumen yang digunakan dalam suatu penelitian (Sugiyono, 2015). Dengan demikian uji vadilitas merupakan pengukuran ketepatan atau kevalidan dalam suatu instrumen yang diukur dan suatu alat ukur dapat dikatakan mempunyai validitas tinggi apabila dapat dijalankan peran ukurnya atau memberikan hasil ukur yang sesuai dengan harapan dan tujuan dari diadakannya tes atau penilaian tersebut.

Validitas suatu butir pertanyaan dapat dilihat dari output StatisticalProgram For Social Science (SPSS) pada pada tabel dengan judul ItemTotal Statistisc.Suatu butir persoalan dikatakan valid jika nilai dari Corrected Item-Total Corrected $>0,30$. Uji validitas seharusnnya dilakukan secara terperinci pada lembar kerja yang berlainan antara satu konstruk variabel dengan konstruk variabel yang lain sehingga dapat diketahui butir-butir permasalahanvariabel mana yang paling besar tidak valid. Sehingga pengambilan keputusan adalah:

1. Jika Corrected Item-Total Correlation > 0,30, maka dimensi tersebut valid

2. Jika Corrected Item-Total Correlation< 0,30 , maka dimensi tersebut tidak valid.

Uji reliabilitas adalah uji terhadap instrumen yang bila digunakan beberapa kali untuk mengukur objek yang sama akan menghasilkan data yang sama (Sugiyono, 2015). Oleh karena itu, uji reliabilitas adalah penguiian yang menghasilkan data yang sama dengan melihat tingkat kosistensi dari instrumen yang diukur. Indikator penilaian yang digunakan adalah cronbach's alpa.

Uji reabilitas dapat dilakukan secara bersama - sama atas semua butir pernyataan untuk lebih dari satu variabel, namun sebaiknya uji reliabilitas hendaknya dilakukan pada masing-masing variabel pada lembar kerja yang berlainan sehingga dapat diketahui konstruk variabel mana yang tidak reliabel. Reliabilitas suatu konstuk variabel dikatakan baik jika memiliki nilai Cronbach's Alpha > 0,60. Sehingga pengambilan keputusan adalah :

1. Jika Cronbach's Alpha> 0,60 maka dimensi pernyataan tersebut reliabel.

2. Jika Cronbach's Alpha $\leq 0,60$ maka dimensi pernyataan tersebut tidak reliabe. 
Tabel 1.

Uji Validitas dan Realibiltas

\begin{tabular}{|l|c|c|c|c|l|}
\hline \multicolumn{1}{|c|}{ Variabel } & $\begin{array}{c}\text { Jumlah } \\
\text { Butir } \\
\text { Pertanyaan }\end{array}$ & $\begin{array}{c}\text { Butir } \\
\text { Tidak } \\
\text { Valid }\end{array}$ & $\begin{array}{c}\text { Butir } \\
\text { Valid }\end{array}$ & $\begin{array}{c}\text { Cronbach's } \\
\text { alpa }\end{array}$ & Ket \\
\hline $\begin{array}{l}\text { Komunikasi } \\
\text { Pemasaran } \\
\text { Terpadu }\end{array}$ & 15 & - & 15 & 0,867 & Reliable \\
\hline $\begin{array}{l}\text { Ekuitas } \\
\text { Merek }\end{array}$ & 12 & - & 12 & 0,860 & Reliable \\
\hline $\begin{array}{l}\text { Loyalitas } \\
\text { Konsumen }\end{array}$ & 5 & - & 5 & 0,829 & Reliable \\
\hline
\end{tabular}

Sumber: Data Olahan 2018

\section{Uji Asumsi Klasik}

Uji asumsi klasik yang digunakan yang digunakan pada penelitian ini adalah, uji normalitas, heteroskedastisitas dan multikoleniaritas.

Uji normalitas adalah pengujian untuk mengkaji kenormalan variabel yang diteleti apakah data tersebut berdistribusi normal atau tidak (Sugiyono, 2015). Dapat dikatakan bahwa uji normalitas untuk melihat tingkat kenormalan variabel yang diteliti. Indikator yang digunakan Uji kolmogrov-smirnov dengan pedoman yaitu :

1. Jika nilai signifikansi $>0,05$,maka berdistribusi normal

2. Jika nilai signifikans $<0,05$, maka tidak berdistribusi normal

Uji multikolinearitas bertujuan untuk menguji apakah model regresi terdapat adanya korelasi antar variabel bebas (independen), model regresi yang baik sebaiknya tidak timbul korelasi diantara variabel independen (Ghozali, 2011). Indikator uji multikonearitas yaitu apabila nilai tolerance $>0,1$, dan Variance Inflation Factor (VIF) $<10$ maka tidak terjadi gejala multikonearitas sehingga tidak adanya pengaruh antara variabel yang satu dengan variabel yang lainnya.

Uji heteroskedatisitas bertujuan mengukur apakah dalam model regresi timbul ketidaksamaan varians dari residual satu pemantauan ke pemantauan yang lain. Jika varians dari residual satu peninjauan ke peninjauan lain tetap, maka disebut homoskedatisitas dan jika berlainan disebut heteroskedatisitas. Jenis regresi yang normal adalah yang homokedastisitas atau tidak timbul heteroskedatisitas (Ghozali, 2011)

Uji multikoleniaritas ini dilakukan untuk melihat apakah pada model regresi ditemukan adanya korelasi antara variabel independen. Baroroh (2013: 28) menyatakan pedoman suatu model regresi yang bebas multikoleniaritas apabila mempunyai nilai VIF (variance influence factor) lebih kecil dari 10 dan mempunyai angka tolerance mendekati 1 . Berdasarkan uji meltikolonieritas dapat disimpelkan bahwa variabel bebas dalam penelitian ini bebas dari multikolonieritas, hal ini terbukti dengan didapatnya nilai tolerence untuk ketiga variabel bebas lebih beasar dari 0,10 dan nilai VIF (variance inflation factor) kurang dari 10. 


\section{Analisis Regresi Linear Berganda}

Tujuan menggunakan analisis regresi linear berganda dalam penelitian ini adalah u

ntuk mengetahui pengaruh Komunikasi Pemasaran Terpadu (X1), daan Ekuitas Merek (X2) terhadap Loyalitas Konsumen(Y).

Tabel 2.

Hasil Uji Regresi Linear Berganda

\begin{tabular}{|c|l|c|c|c|}
\hline $\begin{array}{c}\text { Variabel } \\
\text { Terikat }\end{array}$ & \multicolumn{1}{|c|}{$\begin{array}{c}\text { Konstanta dan } \\
\text { Variabel Bebas }\end{array}$} & $\begin{array}{c}\text { Koefisien } \\
\text { Regresi }\end{array}$ & Signifikan & Keterangan \\
\hline \multirow{2}{*}{$\begin{array}{c}\text { Loyalitas } \\
\text { Konsumen } \\
(Y)\end{array}$} & Konstanta (a) & 1,246 & 0,084 & \\
\cline { 2 - 5 } & $\begin{array}{l}\text { Komunikasi } \\
\text { Pemasaran Terpadu }\end{array}$ & 0,302 & 0,047 & H1 Diterima \\
\cline { 2 - 5 } & Ekuitas Merek & 0,493 & 0,003 & H2 Diterima \\
\hline
\end{tabular}

Sumber : Data Olahan 2018

Hasil analisis regresi lineaar berganda dapat diintrepretasikan bahwa variabel Komunikasi Pemasaran Terpadu, Ekuitas Merek Dan Loyalitas Konsumen berpengaruh positif dan signifikan terhadap loyalitas konsumenkarena memiliki nilai signifikan lebih kecil dari $\alpha=0,05$.

\section{PEMBAHASAN}

\section{Pengaruh Komunikasi Pemasaran Terpadu Terhadap Loyalitas Konsumen Pada CV Laris Motor cabang Air Haji}

Berdasarkan hasil pengujian hipotesis pertama, ditemukan bahwa variabel komunikasi pemasaran terpadu berpengaruh positif dan signifikan terhadap loyalitas konsumen pada CV Laris Motor cabang Air Haji.Berdasarkan hasil uji t pada variabel komunikasi pemasaran terpadu nilai signifikansiyang diperoleh sebesar 0,047 yang lebih kecil dari 0,05. Hal ini dapat diartikan bahwa variabel komunikasi pemasaran terpadu berpengaruh positif dan signifikan terhadap loyalitas konsumen, dengan demikian, hipotesis pertama (H1) dalam penelitian ini yang menyatakan bahwa komunikasi pemasaran terpadu berpengaruh signifikan terhadap loyalitas konsumen pada pada CV Laris Motor cabang Air Haji, dinyatakan diterima.

Hasil penelitian ini dengan dengan penelitian Reszetisia Intani (2016) yang menunjukkan bahwa komunikasi pemasaran terpadu memiliki pengaruh yang positif dan signifikan terhadap loyalitas konsumen.

\section{Pengaruh Ekuitas Merek Terhadap Loyalitas Konsumen PadaCV Laris Motor Cabang Air Haji}

Berdasarkan hasil pengujian hipotesis kedua, ditemukan bahwa variabel ekuitas merek berpengaruh positif dan signifikan terhadap loyalitas konsumen pada CV Laris Motor cabang Air Haji. Berdasarkan hasil uji t variabel ekuitas merek memiliki nilai signifikansebesar 0,003 yang lebih kecil dari 0,05. Hal ini dapat diartikan bahwa variabel ekuitas merek berpengaruh positif dan signifikan terhadap loyalitas konsumen, dengan demikian, hipotesis kedua (H2) dalam penelitian ini yang menyatakan bahwa ekuitas merek berpengaruh positif dan signifikan terhadap loyalitas konsumen pada CV Laris Motor cabang Air Haji, dinyatakan diterima. 
Hasil penelitian ini dengan penelitian Fariza Maulidiah, Suharyono,Kadarisman Hidayat(2008)yang menunjukkan bahwa ekuitas merek memiliki pengaruh yang positif dan signifikan terhadap loyalitas konsumen.

Berdasarkan hasil penelitian penulis bahwa penelitian terdahulu dan penelitian sekarang sesuai dengan praktek lapangan yang dilakukan penulis terhadap loyalitas konsumen pada CV.Laris Motor Cabang Air Haji.

\section{KESIMPULAN}

Berdasarkan hasi penelitian penulis lakukan hal ini sesuai dengan praktek lapangan, dapat ditarik kesimpulan sebagai berikut:

1. CV.Laris Motor cabang Air Haji merupakan perusahaan penjualan produk sepeda motor merek Honda

2. Hipotesis 1 diterima, Komunikasi pemasaran terpadu berpengaruh positif dan signifikan terhadap loyalitas konsumen pada CV.Laris Motor cabang Air Haji.

3. Hipotesis 2 diterima, Ekuitas berpengaruh positif dan signifikan terhadap loyalitas konsumen pada CV Laris Motor cabang Air Haji.

4. Komunikasi pemasaran terpadu danEkuitassignifikanterhadaployalitas konsumen pada CV Laris Motor cabang Air HajiartinyaKomunikasi pemasaran terpadu dan Ekuitas secara bersama - sama memiliki pengaruh yang positif dan signifikan terhadap loyalitas konsumen.

Berdasarkan hasil penelitan penulis bahwa penetian terdahulu, dan penetian sekarang sesuai dengan praktek lapangan yang telah dilakukan. Hal ini menyatakan bahwa pelanggan memilikirespon dan tanggapan yang baik terhadap produk yg dijual CV. Laris Motor Cabang Air Haji.

\section{UCAPAN TERIMAKASIH}

Dengan selesainya penulisan artikel ini, penulis mengucapkan terima kasih kepada pihak-pihak yang membantu selama proses penulisan.

1. Bapak Febryandhie Ananda, SE, M.Si, selaku Ketua di STIE “KBP” Padang.

2. Ibu Lidya Martha, SE, MM selaku Wakil Ketua di STIE “KBP” Padang.

3. Ibu Febsri Susanti, SEI, MM selaku Ketua Program Studi Manajemen di STIE "KBP” Padang.

4. Ibu Maria Magdalena, S.Pd, MM, selaku Penasehat Akademik Program Studi Manajemen di STIE “KBP” Padang.

5. Ibu Riri Mayliza, SE, MM, selaku Pembimbing Proposal Skripsi di STIE "KBP" Padang

\section{DAFTAR PUSTAKA}

Andika, A., \& Susanti, F. (2018). Pengaruh Marketing Mix Terhadap Keputusan Pembelian Parfum di Azzwars Parfum Lubeg Padang. https://doi.org/10.31227/osf.io/upgc3 
Aziz, N. (2019). Pengaruh Komunikasi Efektif Terhadap Kepuasan Pelayanan Rumah Sakit Islam Siti Rahmah Padang. https://doi.org/10.17605/OSF.IO/T2H7Y

Aziz, N. (2019). Analisis Pengaruh Kualitas Produk, Harga, Promosi Terhadap Keputusan Pembelian Air Minum Dalam Kemasan (AMDK) Merek Aicos $\begin{array}{llll}\text { Produksi } & \text { Pt. } & \text { Bumi } & \text { Sarimas }\end{array}$ https://doi.org/10.17605/OSF.IO/8XKYB

Aziz, N. (2019). Pengaruh Atribut Produk Terhadap Minat Beli Sepeda Motor Honda Dealer Amanah Lubuk Alung. https://doi.org/10.17605/OSF.IO/BNDAE

Chan, A. (N.D.). Pengaruh Ekuitas Merek Terhadap Proses Keputusan Pembelian Konsumen : Studi Kasus Bank Muamalat Indonesia Cabang Bandung, 6(1), $47-62$.

Chrismardani, Y. (2014). Komunikasi Pemasaran Terpadu :, 8(2), 176-189.

Darmawangsa, A. A. B. (2015). Pengaruh Komunikasi Pemasaran Terpadu Dan Ekuitas Merek Terhadap Loyalitas Konsumen, 4(8), 2163-2175.

Evelina, N. (2012). ( Studi Kasus Pada Konsumen Telkomflexi Di Kecamatan Kota Kudus Kabupaten Kudus ) Nela Evelina , Handoyo Dw , Sari Listyorini Jurusan Administrasi Bisnis Fakultas Ilmu Sosial Dan Ilmu Politik Universitas Diponegoro J1 . Prof . Soedharto Sh Tembalang Semar, (C).

F., \& Afriyeni, A. (2019). Aktivitas Pemasaran Produk Tabungan Pada PT. Bank Pembangunan Daerah (BPD) Sumatera Barat Cabang Utama Padang. https://doi.org/10.31219/osf.io/tf2bz

Fathoni, F. (N.D.). Pengaruh Komunikasi Pemasaran Terpadu Terhadap Ekuitas Merek (.

Ghozali, I. (2011). Aplikasi Analisis Multivariate Dengan Program Ibm Spss 20. In Book (Pp. 1-298). Semarang: Badan Penerbit Universitas Diponegoro.

Hidayati, R. R., \& Marlius, D. (2018). Aktivitas Promosi Dalam Meningkatkan Dana Pihak Ketiga Pada PT. Bank Perkreditan Rakyat (BPR) Batang Kapas Pesisir Selatan. https://doi.org/10.31227/osf.io/8dgqn

Intani, R. (2016). Pengaruh Integrated Marketing Communication.

Jaya, R. S., \& Susanti, F. (2019). Pegaruh Integrated Marketing Communication Terhadap Brand Equity Pada Mc Donalds A.Yani Padang. https://doi.org/10.31227/osf.io/4ebk2 
Kamener, D. (2017). Faktor - Faktor Yang Mempengaruhi Kualitas Strategi Bersaing Industri Ukm Bordiran / Sulaman Di Kota Padang. Journal Of Economic And Economic Education, 5(1), 90-105. Https://Doi.Org/Doi.Org/10.22202/Economica.2015.5.1.688

Maulidiah, F. (N.D.). Pengaruh Ekuitas Merek Terhadap Loyalitas Pelanggan.

Marlius, D. (2017). Keputusan Pembelian Berdasarkan Faktor Psikologis Dan Bauran Pemasaran Pada PT. Intercom Mobilindo Padang. Jurnal Pundi. Volume 1. No. 1. Hal. 57-66. https://doi.org/10.31575/jp.v1i1.9

Marlius, D. (2016). Pengaruh Bauran Pemasaran Jasa Terhadap Minat Nasabah Dalam Menabung Pada Bank Nagari Cabang Muaralabuh. https://doi.org/10.31227/osf.io/vdqgx

Mayliza, R. (2019). Pengaruh Kesadaran Merek, Asosiasi Merek Dan Perception Of Quality Terhadap Keputusan Pembelian Hospital Bed Merek Paramout Di PT. Aga Medika Utama Padang (Studi Kasus Rumah Sakit Umum Kota Padang). https://doi.org/10.17605/OSF.IO/VYQ4E

Prabowo, N. S., \& Fathoni, A. (2016). Pengaruh Kepuasan Kerja Dan Stres Kerja Terhadap Engangement Employee Dengan Turnover Intention Sebagai Variabel Intervening Pada Pt. Ara Shoes Semarang. Jurnal Manajemen, 17.

Sugiyono. (2015). Statistik Nonparametris Untuk Penelitian. Book. Bandung: Cv. Alvabeta.

Susanti, F. (2015). Pengaruh Bauran Promosi Terhadap Keputusan Klien Dalam Memilih Radio Carano Sebagai Media Promosi Iklan. https://doi.org/10.31227/osf.io/b9ws7

Susanti, F., \& Gunawan, A. C. (2019). Pengaruh Bauran Promosi Dan Harga Terhadap Keputusan Pembelian Produk Kosmetik Maybelline Di Kota Padang. https://doi.org/10.31227/osf.io/npjqh

Widayati, R. (2019). Aktivitas Pemasaran Produk Simpanan PT. Bank Tabungan Negara (Persero)Tbk Kantor Cabang Padang. https://doi.org/10.17605/OSF.IO/3Z5YC

Widayati, R. (2019). Aktivitas Pemasaran Produk Tabungan Pada PT. Bpr Rangkiang Denai Payakumbuh Barat. https://doi.org/10.17605/OSF.IO/S3UZM 